\title{
THE SOUTH AFRICAN LAW ON "PRODUCTS LIABILITY" - QUO VADIS?
}

\author{
Johann Basson $^{1}$
}

\begin{abstract}
Historically the term "products liability" has been confined to the law of delict, and is defined as the liability that arises when a product contains a defect which leads to damage such as to property (patrimonial loss), the death of a person, bodily harm, pain and suffering, shock, discomfort, deformity, loss of amenities or shortened life expectation.
\end{abstract}

It is the author's view that the term "products liability" becomes a misnomer if limited to the law of delict. The author propagates the idea that "products liability" must mean liability arising when a person renders a product unsafe together with a reasonable foreseeable risk of another person(s) being exposed to the unsafe product under circumstances where reasonable precautions could have been taken to prevent it. Such liability arises irrespective as to whether such product actually causes damage, harm or death, and irrespective of whether the product is exposed to the public domain or not and irrespective as to whether the case is based on civil or criminal proceedings.

Subsequently the question is investigated: "Has our law on products liability kept pace with technological, social and economic developments?"

\section{Opsomming}

Histories is die begrip "produkte-aanspreeklikheid" beperk tot die terrein van die deliktereg. Dit word gedefinieer as die aanspreeklikheid wat ontstaan deurdat 'n produk 'n defek bevat wat aanleiding gegee het tot skade, soos aan eiendom, die dood van 'n persoon, liggaamlike beserings, pyn en lyding, skok, ongerief, verminking, verlies aan lewensgenietinge of 'n verkorte lewensverwagting.

Dit is die outeur se siening dat die begrip "produkte-aanspreeklikheid" 'n verkeerde benaming word indien beperk tot die terrein van die deliktereg. Die outeur huldig die siening dat "produkte-aanspreeklikheid" moet beteken aanspreeklikheid wat volg wanneer 'n persoon 'n produk onveilig maak tesame met 'n redelike voorsienbare risiko dat 'n ander persoon(e) aan die onveilige produk blootgestel kan word onder omstandighede waar hy redelike stappe kon

${ }^{1}$ LL.M., M.Sc. (Physics), Pr.Sci.Nat. Affiliation: CSIR, P O Box 395, Pretoria. 
geneem het om dit te voorkom. Sodanige aanspreeklikheid ontstaan ongeag of sodanige produk inderdaad skade, besering of dood veroorsaak het, ongeag of the publiek aan die produk blootgestel word al dan nie, en ongeag of die saak gebaseer is op siviele of kriminele aksies.

Vervolgens word die vraag behandel: "Het ons reg betreffende produkte-aanspreeklikheid tred gehou met tegnologiese, sosiale en ekonomiese verwikkelings?" 


\section{Introduction}

The $21^{\text {st }}$ century holds the prospect of products of increasing technological sophistication appearing on the world market. Indications are that the focus will be in the areas of information and communications technology on the one hand and biochemical products on the other hand. Cloning and gene engineering will contribute to this exciting scenario. Mass production and trading across national boundaries will be part of the scene. Electronic commerce and workflow management utilising the Internet will increase. Service delivery will increasingly include knowledge transfer. South Africans will be exposed to these products, whether as buyers, users, consumers or merely as bystanders. They need to be protected against unsafe products and need to have a legal system that will ensure that, as consumers or bystanders, they will receive adequate compensation where an unsafe product may lead to damage or harm. On the other hand, South Africans will become more and more involved in the importation, design, manufacture, distribution, selling and export of products. They need to have confidence in the legal system for protection against trivial and inflated claims. The level of predictability of the outcome of any claim will determine the community and the parties' level of confidence in the legal system governing products liability. As will be shown, this confidence driver will help determine the extent of the burden a party has to discharge and the evidence required to succeed in his claim or to prevent liability.

Historically the term "products liability" has been confined to the law of delict and is defined as the liability that arises when a product contains a defect which leads to damage to property (patrimonial loss), the death of a person, bodily harm, pain and suffering, shock, discomfort, deformity, loss of amenities or shortened life expectation. Liability may arise because the product may have design or manufacturing defects that renders it unreasonably dangerous or unsafe. Liability may also arise where essential information relating to the product, its suitability for use and its application was lacking or misleading [6]. One should remember that in many cases no contractual agreement between the plaintiff and the defendant exists. In the Anglo-American countries the equivalent of the law of delict is "the law of tort" - the word "tort" having been derived from the Latin word tortus meaning "wrong".

In Kroonstad Westelike Boere-Ko-operatiewe Vereniging Bpk $v$ Botha and Another [1] the following rule was formulated relating to a merchant seller's liability for defects in the goods sold:

"[L/iability for consequential damage caused by latent defect attaches to a merchant seller, who was unaware of the defect, where he publicly professes to have attributes of skill and expert knowledge in relation to the kind of goods sold .... Whether a seller falls within the category mentioned will be a question of fact and degree, to be decided from all the circumstances of the case. Once it is established that he does fall within that category, the law irrebuttably attaches to him the liability in question, save only where he has expressly or by implication contracted out of it." 
In Langeberg Voedsel Bpk $v$ Sarculum Boerdery Bpk [2], Judge Schutz criticised the Kroonstad rule and pointed out that in modern commerce the merchant is not really in a position to assess the safety of the packaged product: "The merchant is denied the opportunity to see, to feel or to smell the produce that passes through his hands. He can as little examine the metal in the bearings as the beans in the tin or the chip in the computer. ... It seems to me cumbrous, wasteful and uncertain of result, and therefore unjust, to require a buyer to prove and a seller to resist in case after case the proposition that the latter publicly professes to have attributes of skill and expert knowledge in relation to particular goods."

Judge Schutz made the statement that our law on products liability may be perceived to be lagging behind in meeting the needs of society. This may be even more true in the current Internet age.

The question may rightly be posed: "Regarding the risk of products liability, does the South African law provide a win-win situation for the product importer / designer / manufacturer / distributor/ seller on the one hand and on the other hand those persons exposed to an unsafe product?"

One can expect that in this age of transparency and exchange of knowledge, the public at large will increasingly become aware of their rights relating to products liability.

It seems appropriate to take stock of the current South African law relating to products liability as seen in the light of the recent judgement in Body Corporate of Greenwood Scheme v 75/2 Sandown (Pty) Ltd and Others [22].

This article does not address liability that flows from a breach of contract and is not intended to be a comprehensive treatise on products liability and related laws, but the intention is to challenge present legal thinking around products liability and the road ahead.

\section{Definition of "product" for purposes of products liability}

The American Product Liability Fairness Act of 1995 defines in section 101 (13) "product" as follows:

“(A) In general: The term 'product' means any object, substance, mixture, or raw material in a gaseous, liquid, or solid state that -

(i) is capable of delivery itself or as an assembled whole, in a mixed or combined state, or as a component part or ingredient; 
(iii) has intrinsic economic value; and

(iv) is intended for sale or release to persons for commercial or personal use.

(B) Exclusion: The term 'product' does not include-

(i) tissue, organs, ... ; and

(ii) electricity, water delivered by a utility, natural gas, or steam."

The Japanese Product Liability Law, No. 85 of 1994, defines "product" as "moveable property manufactured or processed". Incorporeal property such as services, information, software, electricity, etc., and other immovables are excluded.

The Occupational Health and Safety Act 85 of 1993 does not define "product" or "service".

In terms of SABS ISO 8402 (1994) [3], section 1.4, a "product" may include a service. A product can be in tangible form or intangible form (for example knowledge or concepts) or a combination thereof. In terms of section $1.5 \mathrm{a}$ "service" is the result generated by activities at the interface between the supplier and the customer and by the supplier's internal activities to meet the customer needs.

\section{Products liability in terms of the South African common law}

Legal liability may arise from amongst others a breach of contract or from delict. A delict is an unlawful act or omission, causing damage (patrimonial damage) or harm to the aggrieved person. Such act can be intentional or may arise through negligence. The law of delict is part of our common law, which is customary law as further developed by our higher courts and followed by the lower courts (the doctrine of precedence).

In terms of our law of delict [4], a person can only be found products liable if the following five requirements are all met:

a) There must have been a voluntarily, although not a willed, act or omission to act. Such act must have been, at the time of the act, susceptible to will control. Such act can be intentional or may arise through negligence; 
b) The act or omission must have been unlawful. The unlawfulness is to be found in the infringement of the plaintiff's subjective right(s) as measured against the common law doctrine of "duty of care", that is, the sense of justice of the community. For the purpose of this article, let us ignore the grounds for justification;

c) The defendant must be blameworthy for the damage or harm. He must be at fault. Fault means that the defendant acted intentionally or negligently. As in the case of unlawfulness, negligence is measured against the doctrine of "duty of care". The doctrine applies the test question: "Could a reasonable prudent man under the particular circumstances have reasonably foreseen the likelihood that his act could cause damage and / or injury, and could he have taken reasonable precautions to prevent it?" It is not a requirement that the extent or precise nature of the actual damage / harm or the exact manner in which the damage / harm had occurred should have been foreseen by the defendant [7].

The exception to the fault principle is faultless liability called "strict liability" or "risk liability" [4]. Risk liability is based on the wrongful causation of damage / harm through a juridical relevant risky activity, the activity as measured against the doctrine of "duty of care" [5];

d) There must be a causal link between the act, the impairment on the subjective rights and the damages and / or harm. Whether such a causal link exists is a factual question to be answered from the evidence and to be proved on a balance of probabilities; and

e) Patrimonial damages and / or harm on the side of the plaintiff.

\section{Our common law and the plaintiff's burden to prove delictual liability}

As a general rule, he who claims has the burden to prove his case. The plaintiff will allege that the designer, manufacturer or distributor was negligent, reckless or careless in the design, manufacture or distribution of the product as the case may be. For our purpose the seller is seen on the same footing as the distributor.

It may be said that the plaintiff has an unreasonable burden to prove fault, on a balance of probabilities, on the side of the designer, manufacturer or distributor. As a minimum the plaintiff will have to prove negligence. It is difficult for the plaintiff to prove negligence where the product is complex and the plaintiff does not have access to the know-how and the workplace of the designer, manufacturer or distributor. The problem becomes complicated 
when considering that the product may have been manufactured abroad and handled by many distributors and merchant sellers.

The author is of the opinion that this burden may not be as heavy as appears at first glance. Our courts may, on policy grounds, that is the sense of justice of a particular community, come to the assistance of the plaintiff by following the Anglo-American court practice of implementing the maxim res ipsa loquitur (the facts speaks for itself) [5] where the plaintiff claims that the product was "unreasonably dangerous" or "unsafe" and that the facts are such that an inference of negligence can be made [6]. This means that the plaintiff only has to prove that the product was unreasonably dangerous, for instance when it left the factory floor, from which the courts will make the inference of negligence on the part of the designer or manufacturer or distributor, as the case may be. The onus will then shift to the designer, manufacturer or distributor to convince the court with factual evidence that he applied due diligence on his part in the designing, developing or distributing of the product.

The designer, manufacturer or distributor will need to prove to the court that he acted as a reasonable designer, reasonable manufacturer or reasonable distributor to ensure a safe and reliable product. In accordance with the doctrine of "duty of care", the following test is applied: "Could a reasonable prudent designer, manufacturer or distributor under the particular circumstances have reasonably foreseen the likelihood that his act could cause damage and / or injury, and could he have taken reasonable precautions to prevent it?"

The merchant seller or distributor cannot be held liable for a latent defect in a product unless he publicly professes to have attributes of skill and expert knowledge in relation to the kind of goods sold [1]. However, he may for instance become liable by handling safe products contrary to the manufacturer's instructions causing the product to become unsafe, for example by exposing medicine to excessive heat or sunlight during transportation thereof.

The sense of justice of an industrialised society dictates that where the designer and manufacturer represent themselves as specialists relating to such products, the community holds them responsible for keeping abreast of the latest technological trends and for having the capability to design and manage quality and safety into the products. Where the defendant actually professed to be a specialist, the doctrine would apply the test: "Could a reasonable prudent specialist designer, specialist manufacturer or specialist distributor under the particular circumstances have reasonably foreseen the likelihood that his act could cause damage and / or injury, and could he have taken reasonable precautions to prevent it?"

One should remember that a products liability court case might arise several years after the product left the production floor. The question is whether the designer or manufacturer will be able to convince the court on a balance of probabilities that he exercised due diligence in having had an acceptable quality system in position to ensure safe products. It speaks for itself that safely archived documented evidence will be a valuable source to prove due diligence in having designed or manufactured a safe product. 


\section{The master - servant relationship, mandator - mandatory relationship and products liability in the common law}

People management, information management and process management are important functions in the governance of an entity and delivery of products [12]. Needless to say, employees and mandatories (sub-contractors) play pivotal roles.

According to our common law a person can only be held liable for his own delictual acts. However, our common law also makes provision for so-called vicarious liability in the case of a master-servant relationship whereby a master can be held "strict liable", that is liability without fault, for a delict committed by his servant. In today's terms we would refer to this relationship as an employer-employee relationship. The vicarious liability principle is based on social policy, that is, based on the society's legal convictions [4]. Society has the notion that the employer, who as part of his profitable operations, creates a risk by employment of an employee, must bear the consequences of any wrongful act by the employee [13]. A claimant would normally direct his action against the employer, knowing that the employer is in a stronger position to compensate for the claimant's losses than the employee. Having compensated a successful claimant, the employer may redress his losses from the employee, depending on the circumstances of the case.

The crucial question is where does the employer's vicarious liability for the wrongful acts of the employee begin and end.

In general an employer is vicariously liable for the delictual acts of his employee committed in the "scope and course of employment". The question is what is meant with "in the scope and course of employment".

In Rodrigues and Others $v$ Alves and Others [15] the Court held that remuneration (of a servant) in itself is not an essential condition for a master-servant relationship. Also that the requirement of control does not mean actual control - a servant allowed a certain amount of discretion in executing his task does not imply that he is not a servant.

The tasks (the "what") that an employee must perform may be spelled out, but the risks of delictual liability may lie in the manner or mode of executing the function (the "how").

In the case of Romansrivier Koöp Wynkelder $v$ Chemserv Manufacturing [16] Judge Van Deventer stated: "However, it seems to me to be settled law now that the question whether the servant can be said to have acted within the course or scope of his employment may, depending on the circumstances of each case, be subjugated to the question whether the act falls within the risk 
created by his employment ... ." The Judge then quoted Watermeyer CJ in Feldman (Pty) Ltd $1945 \mathrm{AD} 733$ : “. .. a master who does his work by hand of a servant creates a risk of harm to others if the servant prove to be negligent or inefficient or untrustworthy; that, because he has created this risk for his own ends he is under a duty to ensure that no one is injured by the servant's improper conduct or negligence in carrying on his work ..."

Can a permanent employer become vicariously liable for damages or harm sustained by a third party as a result of the employee's negligence where the services of the employee had been contracted out to another party (temporary employer)?

In $R$ H Johnson Crane Hire (Pty) Ltd v Grotto Steel Construction (Pty) Ltd [13] the Court accepted that in the case of temporary workers the criterion of the temporary employer's control over the servant affords the best indication as to where to place the liability for the risk of damage or harm: with the temporary employer or the permanent employer (who for instance lets his crane and the services of his operator-servant to the temporary employer). The Court held that the key question relating to this control over the servant is whether the temporary employer had the right or power to exercise control over the manner in which the employee rendered his services (for instance to give instructions to the operator how to handle the crane). In Midway Two Engineering \& Construction Services BK v Transnet Bpk. [14] the Supreme Court of Appeal confirmed the view taken in the Johson Crane Hire case and highlighted that there were a variety of factors to take into account to determine the relationship between employer and employee for the purpose of vicarious liability, of which the right of supervision and control is one.

Can an employer of a professional person such as a professional engineer or professional natural scientist be held vicariously liable for the delictual deeds of such employee notwithstanding that such a professional person has a large amount of freedom in the exercising of his / her duties? The Supreme Court in Mtetwa $v$ Minister of Health [19] held that an employer is at risk if a member of staff under his command is negligent in the exercise of any of his duties, be they professional and not subject to dictation from others, even if the latter exercised a discretion of his own, or even when he was not on duty.

As a general rule our law does not recognise vicarious liability of a mandator for the delict committed by his mandatory (also called an "independent contractor") which he contracted ("employed"). The term "employed" is normally utilised in the context of employer employee relationships and not with mandator - mandatary relationships [17].

However, in the appellate case Langley Fox Building Partnership (Pty) Ltd v De Valente [18], Goldstone AJA stated that it is a fundamental rule of our law that a person is obliged to exercise that degree of care which circumstances demand. Whether the circumstances demand the exercise of care will depend upon proof that the mandator owed the plaintiff a duty of care and that the damage suffered was not too remote. The judge defined the tests to determine whether the mandator acted negligently as follows: 
“(1) Would a reasonable man have foreseen the risk of danger in the consequence of the work he employed the contractor to perform? If so,

(2) would a reasonable man have taken steps to guard against the danger? If so,

(3) were such steps duly taken in the case in question?

Only where the answer to the first two questions is in the affirmative does a legal duty arise, the failure to comply with which can form the basis of liability. ...

It follows from the aforegoing that the existence of a duty upon an employer of an independent contractor to take steps to prevent harm to members of the public will depend in each case upon the facts. It would be relevant to consider the nature of the danger; the context in which the danger may arise; the degree of expertise available to the employer and the independent contractor respectively; and the means available to the employer to avert the danger. This list is in no way intended to be comprehensive."

\section{Limitation on liability in the common law}

Establishing the extent of products liability becomes problematic if the act led to a chain of events and remote consequences.

The defendant is only liable for those damages and harm if not only the consequences but also the causal connection between the act and the consequences were reasonably foreseeable. The test for "reasonable foreseeability" centres around the question whether, at the time of the delict, the consequences and the causal connection between the act and the consequences in general were foreseeable with such a degree of probability that the consequences can be reasonably imputed to the defendant. This test must not be confused with the "duty of care" test for negligence.

There is a distinction between factual and legal causation. Although a delictual act may result in a cascade of different losses (factual causation), the defendant may only be held liable for those losses where there is a legal causation between the act and the loss. Factual causation is determined from the evidence by analysing how one fact follows from another.

In Shrog v Valentine [11] Judge Clayden explained that where a wrong has caused destruction of a plaintiff's property, damages based on the value of the property together with any consequential loss such as a loss of actual profits due and traceable to the destruction, are recoverable.

Legal causation is established in that the courts follow a supple approach and may apply considerations of policy guarding against exceeding the boundaries of reasonableness, 
fairness and justice [8] [9] [10]. Considerations of policy may differ between communities depending on the sense of justice of that particular community.

\section{The South African Bill of Rights}

The South African Bill of Rights states in section 24:

\section{"24. Everyone has the right}

to an environment that is not harmful to their health or well-being; ... "

In applying any considerations of policy, the courts must take into account the sense of justice of the community, also known as the "boni mores", within the context of the South African Bill of Rights.

\section{8. "Products liability" and the Occupational Health and Safety Act 85 of 1993}

Section 10(1) of this Act states amongst others that any person who designs, manufactures, imports, sells or supplies any article for use at work must ensure as far as is reasonably practicable that the article is safe and without risks to health when properly used and that it complies with all prescribed requirements. [My emphasis by underlining.]

Similarly, section 10(3) requires that any person who manufactures, imports, sells or supplies any substance for use at work must ensure as far as is reasonably practicable, that the substance is safe and without risks to health when properly use. Furthermore, such person must take the necessary steps to ensure that information is available with regard to the use of the substance at work, the risks to health and safety associated with such substances, the conditions necessary to ensure that the substance will be safe and without risks to health when properly used and the procedures to be followed in the case of an accident involving such substance. [My emphasis by underlining.]

Per definition "sell" includes an offer or display for sale or importation into South Africa for sale, or an exchange, donation, lease or offer or display for leasing.

Any person who erects or installs any article for use at work on or in any premises shall ensure, as far as is reasonably practicable, that nothing about the manner in which it is erected or installed makes it unsafe or creates a risk to health when properly used (section 10(2)). 
Section 10(4) makes provision for a shift of accountability:

“10. (4) Where a person designs, manufactures, imports, sells or supplies an article or substance for or to another person and that other person undertakes in writing to take specified steps sufficient to ensure, as far as is reasonably practicable, that the article or substance will comply with all prescribed requirements and will be safe and without risks to health when properly used, the undertaking shall have the effect or relieving the first-mentioned person from the duty imposed upon him by this section to such an extent as may be reasonable having regard to the terms of the undertaking."

Section 10(4) does not refer to a so-called "voetstoots" clause. Such clause does not relieve one from the obligations in terms of section 10(4).

It should be highlighted that the person who transfers the article or substance to another, has a legal duty to disclose to the other person any unsafe hidden latent defects known to the transferor but not visible or discoverable upon inspection of the product by the transferee. Take for instance the following example: where a vacuum pump is contaminated with highly toxic material, the latent defects and inherent dangers must be highlighted in the written undertaking.

According to section 22, if any requirement has been prescribed in respect of any article, substance, plant, machinery or health and safety equipment or the use or application thereof, then no such items may be sold or marketed unless it complies with the requirements.

Section 37(1) places certain burdens of proof on the employer to prove his innocence:

"37. (1) Whenever an employee does or omits to do any act which it would be an offence in terms of this Act for the employer of such employee or a user to do or omit to do, then, unless it is proved that-

(a) in doing or omitting to do that act the employee was acting without the connivance or permission of the employer or any such user;

(b) it was not under any condition or in any circumstance within the scope of the authority of the employee to do or omit to do an act, whether lawful or unlawful, of the character of the act or omission charged; and

(c) all reasonable steps were taken by the employer or any such user to prevent any act or omission of the kind in question,

the emplover or any such user himself shall be PRESUMED to have done or omitted to do the act, and shall be liable to be convicted and sentenced in respect thereof; and the fact that he issued instructions forbidding any act or omission of 
the kind in question shall not, in itself, be accepted as sufficient proof that he took all reasonable steps to prevent the act or omission." [My emphasis by using capital lettering and underlining.]

"User" is the person who uses a plant or machinery for his own benefit or who has the right of control over the use of the plant or machinery but excludes the lessor thereof or a person employed in connection with the plant or machinery.

Section $37(2)$ states that section $37(1)$ similarly applies to a mandatory of any employer or user unless the parties have agreed in writing that the mandatory undertook it upon himself to comply with the provisions of the Act.

Section 37(3) states that whenever an employee or mandatory of an employer or user does or omits to do an act which would be an offence in terms of this Act for the employer or such user to do or omit to do, he shall be liable to be convicted as if he was the employer or user.

Section 39(5) also shifts the burden of prove to the accused:

"39. (5)(a) Whenever at the trail of any person charged with a contravention of section 22 it is proved that the accused sold or marketed any article, substance, plant, machinery or health and safety equipment contemplated in that section, it shall be PRESUMED, until the contrary is proved, that such article, substance, plant, machinery or health and safety equipment did not at the time of the sale or marketing thereof comply with the said requirements." [My emphasis by using capital lettering and underlining.]

Failure to comply with section $10(1)-10(3)$ or section 22 amounts to a criminal offence.

9. Section 424(1) of the Companies Act and section 64(1) of the Close Corporations Act

Section 424(1) of the Companies Act 61 of 1973 reads:

"When it appears, whether it be in a winding-up, judicial management or otherwise, that any business of the company was or is being carried on recklessly or with intent to defraud creditors of the company or creditors of any other person or for any fraudulent purpose, the Court may, on the application of the Master [of the Court], the liquidator, the judicial manager, any creditor or member or contributory of the company, declare that ANY PERSON who was knowingly a party to the carrying on of the business in the manner aforesaid, shall be PERSONALLY responsible, without any limitation of liability, for all or any of the debts or 
liabilities of the company as the Court may direct." [My emphasis by using capital lettering and underlining.]

Section 64(1) of the Close Corporations Act follows the same line.

\section{0. "Products liability" in the light of the decision in Body Corporate of Greenwood Scheme $v 75 / 2$ Sandown (Pty) Ltd and Others}

In Body Corporate of Greenwood Scheme v 75/2 Sandown (Pty) Ltd and Others the plaintiff, a body corporate, instituted action against the sole director of a building company. The plaintiff alleged that the director had knowingly been a party to the company performing the building activities in a reckless manner with the result that the plaintiff sustained damages in respect of repairs and renovations and consequently that the director should be personally liable in terms of section 424(1).

The Court held the view that reference to the business of the company in section 424 embraced more than merely financial affairs. The Court also held that a director could be held liable even when the company is in a sound financial position and still carrying on with its business.

At 488I Wepener AJ made the following important statement:

"The reference to the liability in terms of $s 424$ is in any event complimentary to the third defendant's [the director in this case] common-law liability, which would be based on the same facts alleged by the plaintiff in order to sustain the claim in terms of $s 424$ of the Companies Act. The purpose of 5424 (1) was to supplement the common law and to simplify the evidential requirements of a delictual claim which might be difficult if not impossible to prove." [My emphasis by underlining.]

Thus, any person who was knowingly a party to the carrying on of the business of the company in a reckless manner such as the introduction of a dangerous defect or unsafety into the product through design, manufacture, distribution, selling, installation, maintenance, repair, refurbishment, reconditioning or b) by not providing essential information relating to the product, its suitability for use and its application, shall be personally responsible, without any limitation of liability, for all or any of the debts or liabilities of the company as the Court may direct.

The ordinary meaning of "recklessly" includes gross negligence, with or without consciousness of risk-taking. In Philotex (Pty) Ltd and Others $v$ Snyman and Others [20] the Court confirmed the view taken in $S v$ Dhlamini [21], namely that gross negligence includes 
"an attitude or state of mind characterised by 'an entire failure to give consideration to the consequences of one's actions, in other words, an attitude of reckless disregard of such consequences","

\section{Products liability in other legal systems}

Whereas South Africans will increasingly import and export products, it is advisable to take cognisance of developments abroad in the arena of products liability.

Japan has moved away from the fault-based liability (negligence) principle as a condition for liability to a defect-based liability, also known as "strict liability" by adopting their Product Liability Law, No. 85 of 1994.

It is noteworthy that this law makes provision for a "development risk defence" as a ground for exemption. This means that the designer, manufacturer and distributor shall not be liable for damages and harm if he can prove that the "scientific or technological knowledge" at the time when he delivered the product was not such that he could have detected the defect before release.

This Act also makes provision for a prescription period of ten years from date of release of the product after which no liability claims may be instituted.

The United States' Product Liability Fairness Act of 1995 defines "product liability action" as meaning "a civil action brought on any theory for harm caused by a product." [My emphasis by underlining.] It appears that the applicant may resort to either fault-based liability or strict liability.

It is interesting to note how the USA legislature addressed the liability of the "product seller". In section 101 (15) "product seller" is defined as a person who:

"[(A)](i) in the course of a business conducted for that purpose, sells, distributes, rents, leases, prepares, blends, packages, labels, or otherwise is involved in placing a product in the stream of commerce; or

(ii) installs, repairs, refurbishes, reconditions, or maintains the harm-causing aspect of the product."

The term does not include a provider of professional services in any case in which the sale or use of a product is incidental to the transaction and the essence of the transaction is the furnishing of judgement, skill or services." 
In terms of section 104 of the United States' Product Liability Fairness Act of 1995, a claimant must establish, amongst others, that the product seller made an express warranty applicable to the product that allegedly caused the harm that is the subject of the complaint, independent of any express warranty made by a manufacturer as to the product, and that the product failed to conform to the warranty and that the failure of the product to conform to the warranty caused harm to the claimant. The seller needs to exercise reasonable care with respect to the product. A product seller shall not be considered to have failed to exercise reasonable care with respect to the product if the product seller had no reasonable opportunity to inspect the product that allegedly caused the harm.

What about importers of goods that are unsafe? Section 104:

"A product seller shall be deemed to be liable as a manufacturer of a product for harm caused by the product if -

(A) the manufacturer is not subject to service of process under the laws of any State in which the action may be brought; or

(B) the court determines that the claimant would be unable to enforce a judgment against the manufacturer."

\section{Conclusions}

This article highlighted several ways in which a person can be held liable for an unsafe product. Damage, death or harm is not a requirement in all cases. It is for this reason that the term "products liability" should not be confined to the area of the law of delict, but should have a wider connotation.

It is my view that "products liability" must mean liability arising when a person renders a product unsafe, together with a reasonable foreseeable risk of another person(s) being exposed to the unsafe product under circumstances where reasonable precautions could have been taken to prevent it. Such liability arises irrespective of whether such product indeed actually causes damage, harm or death, and irrespective of whether the product is exposed to the public domain or not and irrespective of whether the case is based on civil or criminal action.

Has our law on products liability kept pace with technological, social and economic developments? Does our common law and legislation such as the Occupational Health and Safety Act, section 424 of the Companies Act and the decision in Body Corporate of Greenwood Scheme v 75/2 Sandown (Pty) Ltd and Others currently reasonably meet the community's sense of justice by adequately setting out the boundaries within which product safety must be managed? I believe that our law has reasonably kept pace with developments to meet the needs of the community. 
However, there are areas for improvement such as to meet the need for an unambiguous and concise definition of the concept "product", especially when considering this age of knowledge sharing and service delivery.

\section{Acknowledgements}

The author wishes to thank Ms Ilse Lombard from CSIR Legal Services for her valuable advice and peer review.

\section{References}

[1] Kroonstad Westelike Boere-Ko-operatiewe Vereniging Bpk v Botha and Another 1964 (3) SA 561 (A).

[2] Langeberg Voedsel Bpk $v$ Sarculum Boerdery Bpk 1996 (2) SA 565 (AA).

[3] SABS ISO 8402 (1994) Quality management and quality assurance - Vocabulary, 1st ed. Pretoria: SABS.

[4] Van der Walt, J C and Midgley, J. R. (1997) Delict. Principles and Cases. 2nd ed. Vol. 1. Durban: Butterworths.

[5] Van der Walt, J C. (1974) Risiko-aanspreeklikheid uit onregmatige daad. LL.D Thesis. University of South Africa.

[6] Bayer South Africa (Pty) Ltd and Another v Viljoen 1990 (2) SA 647 (AD).

[7] Clinton-Parker v Administrator, Transvaal. Dawkins v Administrator, Transvaal 1996 (2) SA 37 (WLD).

[8] Sv Mokgethi 1990 (2) SA (A).

[9] Visser, P. J and Potgieter, J. M. (1993) Skadevergoedingsreg. 1st ed. Kenwyn: Juta.

[10] International Shipping Co (Pty) Ltd v Bentley 1990 (1) SA 680 (AD).

[11] Shrog v Valentine 1949 (3) SA 1228 (T).

[12] The South African Excellence Foundation. (2000). South African Excellence Model. South African Excellence Foundation, Pretoria.

[13] R H Johnson Crane Hire (Pty) Ltd v Grotto Steel Construction (Pty) Ltd, 1992 (3) SA 907 (CPD).

[14] Midway Two Engineering \& Construction Services BK v Transnet Bpk. [1998] 2 All SA 451 (A)

[15] Rodrigues and Others v Alves and Other, 1978 (4) 834 (AD). 
[16] Romansrivier Koöp Wynkelder v Chemserv Manufacturing 1993 (2) SA 358 (CPD).

[17] Colonial Mutual Life Assurance Society Ltd v Macdonald 1931 AD 412.

[18] Langley Fox Building Partnership (Pty) Ltd v De Valente 1991 (1) SA 1 (AD).

[19] Mtetwa v Minister of Health 1989 (3) SA 600 (D \& CLD).

[20] Philotex (Pty) Ltd and Others v Snyman and Others 1998 (2) SA 138 (SCA) together with

Braitex (Pty) Ltd and Others $v$ Snyman and Others 1998 (2) SA 138 (SCA).

[21] Sv Dhlamini 1988 (2) SA 302 (A).

[22] Body Corporate of Greenwood Scheme v 75/2 Sandown (Pty) Ltd and Others 1999 (3) SA $480(W)$. 